\title{
Pengaruh Sales, Working Capital dan Operating Cash Flow Terhadap NetProfit Perusahaan Consumer Goods Listing di Bursa Efek IndonesiaPeriode 2013-2017
}

\author{
Herbert Ernando \\ Universitas Prima Indonesia \\ Binjai, Indonesia \\ herberternando7@gmail.com \\ Stasia \\ Universitas Prima Indonesia \\ Medan, Indonesia \\ stawanggg02@gmail.com
}

\author{
Peni Wati \\ Universitas Prima Indonesia \\ Binjai, Indonesia \\ meinicen@gmail.com \\ Jessica Alexandra S \\ Universitas Prima Indonesia \\ Medan, Indonesia \\ jessicaalexandra474@gmail.com \\ Mas Intan Purba \\ Universitas Prima Indonesia \\ Medan, Indonesia \\ masintanpurba84@gmail.com
}

\author{
Princeslia Desyca \\ Universitas Prima Indonesia \\ Medan, Indonesia \\ princesliadesyca31@gmail.com \\ Wenny Anggeresia Ginting \\ Universitas Prima Indonesia \\ Medan, Indonesia \\ gintinganggresiawenny@gmail.com
}

\begin{abstract}
ABSTRAK
Penyebab persaingan usaha bisnis yang ketat, karena banyaknya perusahaan pesaing yang memiliki kualitas kompetitif yang baik. Salah satunya pada perusahaan sektor industri barang konsumsi. Fenomena yang terjadi di perusahaan adalah peningkatan sales, working capital dan operating cash flow. Masalah dari penelitian dirumuskan sebagai berikut: apakah terdapat pengaruh sales, working capital dan operating cash flow terhadap net profit pada perusahaan consumer goods yang listing di Bursa Efek Indonesia pada periode 2013-2017. Metode penelitian yang digunakan adalah metode penelitian kuantitatif dengan tipe penelitian deskriptif dan sifat penelitian adalah penelitian kausal. Dokumentasi digunakan untuk mengumpulkan data. Analisis regresi linear berganda merupakan metode analisis data, koefisien determinasi, uji $\mathbf{F}$ dan uji t. teknik purposive sampling merupakan teknik pengambilan sampel dengan kriteria tertentu ada 24 perusahaan sebagai sampel penelitian. Berdasarkan hasil penelitian ini menunjukkan bahwa sales, working capital dan operating cash flow secara simultan berpengaruh signifikan terhadap net profit. Secara parsial, sales berpengaruh signifikan terhadap net profit, working capital signifikan terhadap net profit,operating cash flow telah pengaruh signifikan terhadap net profit.
\end{abstract}

Keywords : Sales, Working Capital, Operating Cash Flow, Net Profit

\section{PENDAHULUAN}

Penyebab persaingan usaha bisnis yang ketat, karena banyaknya perusahaan pesaing yang memiliki kualitas kompetitif yang baik. Salah satunya pada perusahaan sektor industri barang konsumsi.

Indonesia mengalami perkembangan pasar modal yang pesat dari periode ke periode, hal itu di tandai dengan adanya jumlah saham yang ditransaksikan dan volume perdagangan di BEI yang mengalami peningkatan.

Saham yang terdapat pada sektor industri barang konsumsi dapat menjadi pilihan dan memiliki prospek yang lebih baik karena produk-produk yang selalu dipenuhi permintaan dan dikuasai oleh permintaan domestik yang cukup tinggi. 
Perusahaan mempunyai peran penting untuk mendapatkan laba bersih untuk menilai kinerja keuangan. Apabila laba bersih meningkat terus menerus, investor akan mengetahuikualitas laba dan tertarik untuk menginvestasikan labanya agar perusahaaan dapat berkembang dengan baik.

Penjualan sangat mempengaruhi perusahaan untuk mendapatkan laba. Semakin ketatnya persaingan dapat menyebabkan perusahaan sulit untuk memperoleh laba. Oleh karena itu perusahaan memberikan kemudahan kepada konsumen dengan produk dijual lebih murah, diskon yang menarik atau memberikan penjualan secara kredit.

Modal kerja yang dikelola dengan baik sangat dibutuhkan dalam suatu perusahaan untuk membiayai dan melangsungkan kegiatan perusahaan. Modal kerja yang menurun dapat menghalangilancarnya kegiatan usaha, sama halnya apabila modal kerja yang semakin tinggi dapat menyebabkan dana yang tidak produktif yang akan mengakibatkan kerugian.
Kemampuan arus kas operasi juga dapat di nilai dari suatu perusahaan yang menggunakan kas tersebut untuk mempertahankan kelangsungan perusahaan dengan berbagai resiko yang dapat terjadi kedepannya. Semakin meningkatnya arus kas operasi yang diterima menyebabkan perusahaan dapat memperoleh laba.

Beberapa fenomena terjadi didalam perusahaan consumer goods yang terdaftar di Bursa Efek Indonesia, diantaranya, Perusahaan Indofood Sukses Makmur pada tahun 2014-2015 penjualan mengalami peningkatan sebesar $0,73 \%$ tetapi laba bersih mengalami penurunan sebesar $-29,08 \%$. Delta Djakarta, Tbk, pada tahun 2014-2015 aktiva lancar mengalami peningkatan sebesar 5,09\% tetapi laba bersih mengalami penurunan $33,43 \%$. Darya Varia Laboratoria, Tbk, pada tahun 2014-2015 arus kas operasi mengalami peningkatan sebesar $105,02 \%$ tetapi laba bersih mengalami peningkatan sebesar $32,23 \%$.

Tabel I.1

Fenomena Penelitian

(Dalam Ribuan Rupiah)

\begin{tabular}{|c|c|c|c|c|c|}
\hline $\begin{array}{c}\text { Nama } \\
\text { Perusahaan }\end{array}$ & Tahun & Penjualan & Aktiva Lancar & $\begin{array}{c}\text { Arus Kas } \\
\text { Operasi }\end{array}$ & Laba Bersih \\
\hline \multirow{4}{*}{$\begin{array}{c}\text { Indofood } \\
\text { Sukses } \\
\text { Makmur, Tbk }\end{array}$} & 2013 & 55.623 .657 .000 & 32.772 .095 .000 & 6.928 .790 .000 & 3.416 .635 .000 \\
\cline { 2 - 6 } & 2014 & 63.594 .452 .000 & 41.014 .127 .000 & 9.269 .318 .000 & 5.229 .489 .000 \\
\cline { 2 - 6 } & 2015 & 64.061 .947 .000 & 42.816 .745 .000 & 4.213 .613 .000 & 3.709 .501 .000 \\
\cline { 2 - 6 } & 2016 & 66.750 .317 .000 & 28.985 .443 .000 & 7.175 .603 .000 & 5.266 .906 .000 \\
\hline \multirow{4}{*}{$\begin{array}{c}\text { Delta Djakarta, } \\
\text { Tbk }\end{array}$} & 2017 & 70.186 .618 .000 & 32.515 .399 .000 & 6.507 .803 .000 & 5.145 .063 .000 \\
\cline { 2 - 6 } & 2013 & 867.066 .542 & 748.111 .003 & 348.712 .041 & 270.498 .062 \\
\cline { 2 - 6 } & 2015 & 879.253 .383 & 858.313 .129 & 164.246 .813 & 288.499 .375 \\
\cline { 2 - 6 } & 2016 & 774.968 .268 & 1.048 .133 .697 & 259.851 .506 & 254.509 .268 \\
\hline \multirow{4}{*}{$\begin{array}{c}\text { Darya Varia } \\
\text { Laboratoria, } \\
\text { Tbk }\end{array}$} & 2017 & 777.308 .328 & 1.206 .576 .189 & 342.202 .126 & 279.772 .635 \\
\cline { 2 - 6 } & 2013 & 1.101 .684 .170 & 913.983 .962 & 106.931 .180 & 125.796 .473 \\
\cline { 2 - 6 } & 2015 & 1.103 .821 .775 & 925.293 .721 & 104.436 .317 & 81.597 .761 \\
\cline { 2 - 6 } & 2016 & 1.406 .098 .136 & 1.043 .830 .034 & 214.116 .823 & 107.894 .430 \\
\hline
\end{tabular}

Sumber : www.idx.co.id

\section{Tujuan Penelitian}

Tujuan penelitian ini adalah sebagai berikut:

1. Untuk menguji dan menganalisis pengaruh penjualan secara parsial terhadap laba bersih pada perusahaan consumer goods di Bursa Efek Indonesia Periode 2013-2017.

2. Untuk menguji dan menganalisis pengaruh modal kerja secara parsial terhadap laba bersih pada perusahaan consumer goods di Bursa Efek Indonesia Periode 2013-2017.

3. Untuk menguji dan menganalisis pengaruh pengaruh arus kas operasi secara parsial terhadap laba bersih pada perusahaanconsumer goods di Bursa Efek Indonesia Periode 2013-2017.

4. Untuk menguji dan menganalisis pengaruh penjualan, modal kerja dan arus kas operasi secara simultan terhadap laba bersih pada perusahaan consumer goods 
di Bursa Efek Indonesia Periode 2013-

2017.

\section{Landasan Teori \\ 1. Sales}

Menurut Soemarso (2009:160), penjualan adalah pendapatan perusahaan dari jumlah yang dibebankan kepada pembeli untuk barang dagang yang di serahkan kepada yang bersangkutan.

Menurut Jumingan (2014:161), tingginya tingkat penjualan mungkin karena rangsangan berupa harga yang lebih rendah dan pemberian potongan harga pada pembelian tunai. Penurunan laba usaha disebabkan oleh tidak menurunkan harga pokok penjualan dan tidak melakukan penghematan biaya usaha.

Menurut Hery (2013:117), untuk menghitung penjualan dapat menggunakan rumus sebagai berikut. Indikator penjualan dalam penelitian ini adalah diambil langsung dari laporan keuangan penjualan bersih yang telah diaudit tahun 2013-2017 di BEI.

\section{Penjualan Bersih $=$ Penjualan - Retur dan Penyesuaian Harga Jual - Potongan Penjualan}

\section{Working Capital}

Menurut Danang (2013:140), modal kerja adalah aktiva lancar yang lebih terhadap utang jangka pendek, yaitu banyaknya jumlah aktiva lancar yang berawal dari pinjaman jangka panjang maupun dari para pemilik perusahaan.

Menurut Fahmi (2012:103), semakin besar perusahaan maka kebutuhan dana untuk menunjang modal kerja juga akan semakin tinggi, dan itu diikuti juga harus semakin tinggi perputaran yang bisa diberikan agar tertutupinya biaya modal kerja yang telah dikeluarkan. Secara konsep ketika turnover penjualan semakin tinggi serta melewati batas biaya modal kerja yang dikeluarkan maka artinya suatu perusahaan dapat memperoleh profit.

Menurut Kasmir (2015:249), untuk menghitung modal kerja dapat menggunakan rumus sebagaiberikut.

Modal Kerja = Aktiva Lancar- Hutang Lancar

\section{Operating Cash Flow}

Menurut Sudana (2011:18), arus kas operasi merupakan kas yang diperoleh dari perusahaan bisnis yang beraktivitas secara normal. Melakukan penghitungan arus kas operasi berdasarkan pada penjualaan yang mengurangi biaya, tetapi tidak menghitung penyusutan karena bukan merupakan pengeluaran kas dan tidak menghitung biaya bunga karena merupakan pengeluaran untuk pendanaan.

Menurut Munawir (2014:158), jumlah kas yang relative rendah akan didapat dari tingkat perputaran kas yang tinggi dan akan mendapatkan laba lebih banyak, tetapi perusahaan hanya berpikir agar dapat memperoleh laba (rentabilitas) tanpa memperhatikan likuiditas akhirnya perusahaan tersebut akan dalam kondisi illikuid jika tiba-tiba ada tagihan.

Menurut Hery (2014:108), rumus untuk menghitung arus kas operasi adalah sebagai berikut. Indikator arus kas operasi dalam penelitian ini adalah diambil langsung dari laporan keuangan arus kas operasi yang telah diaudit tahun 2013-2017 di BEI.

$$
\text { AKO }=\frac{\text { Arus Kas Operasi }}{\text { Laba Bersih }}
$$

\section{Net Profit}

Menurut Brigham dan Houston (2012:108), Laba operasi setelah pajak ialah laba yang akan di peroleh perusahaan jika tidak memiliki hutang dan hanya memiliki aset operasi.

Menurut Kasmir (2015:303), Laba bersih ialah laba yang di kurangi biaya biaya yang merupakan beban perusahaan dalam periode tertentu, termasuk pajak.

Menurut Hery (2013:110), laba/rugi bersih dihitung dari rumus berikut. Indikator laba bersih dalam penelitian ini adalah diambil langsung dari laporan keuangan laba bersih yang telah diaudit tahun 2013-2017 di BEI.

Laba bersih $=$ Total Pendapatan - Total Beban 
Adapun kerangka konseptual dalam penelitian ini adalah:

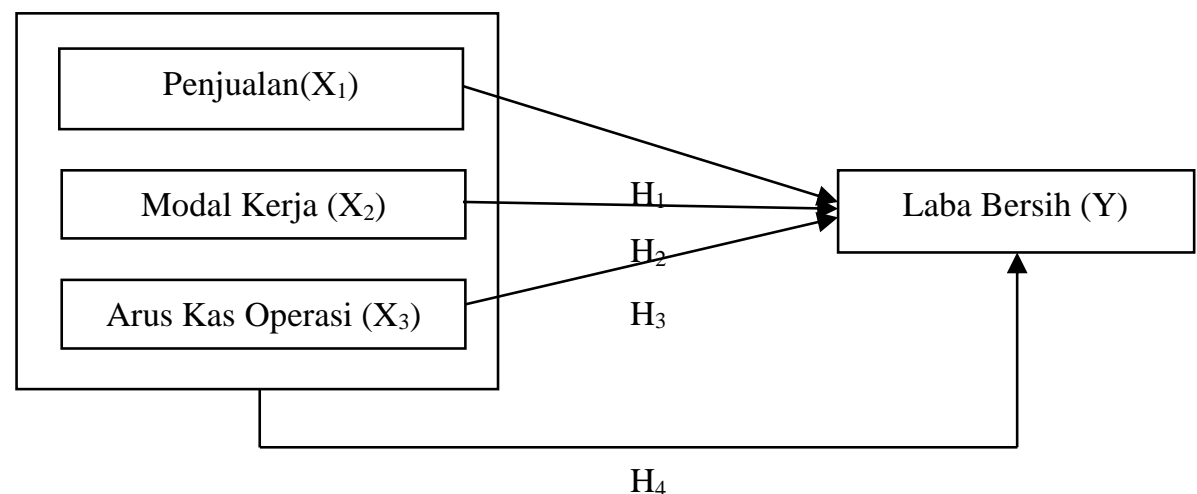

Gambar II.1 Kerangka Konseptual

\section{Hipotesis Penelitian}

Adapun hipotesis penelitian dalam penelitian ini sebagai berikut:

$\mathrm{H}_{1}$ : Penjualan berpengaruh secara parsial terhadap laba bersih pada perusahaan consumer goods yang terdaftar di Bursa Efek Indonesia periode 2013-2017.

$\mathrm{H}_{2}$ : Modal kerja berpengaruh secara parsial terhadap laba bersih pada perusahaan consumer goods yang terdaftar di Bursa Efek Indonesia periode 2013-2017.

\section{Metodologi Penelitian}

Pendekatan penelitian yang dilakukan dalam penelitian ini adalah dengan pendekatan kuantitatif. Menurut Sugiyono (2012:13), metode penelitian kuantitatif dapat diartikan sebagai metode penelitian yang berlandaskan pada filsafat positivisme, digunakan untuk meneliti pada populasi atau sampel tertentu, teknik pengambilan sampel pada umumnya dilakukan secara random, pengumpulan data menggunakan instrument penelitian, analisis data bersifat kuantitatif atau statistik dengan tujuan untuk menguji hipotesis yang telah ditetapkan.
$\mathrm{H}_{3}$ : Arus kas operasi berpengaruh secara parsial terhadap laba bersih pada perusahaan consumer goods yang terdaftar di Bursa Efek Indonesia periode 2013-2017.

$\mathrm{H}_{4}$ : Penjualan, modal kerja dan arus kas operasi berpengaruh secara simultan terhadap laba bersih pada perusahaan consumer goods yang terdaftar di Bursa Efek Indonesia periode 2013-2017.

Jenis penelitian yang digunakan dalam penelitian ini adalah penelitian deskriptif kuantitatif. Menurut Sugiyono (2012:53), penelitian deskriptif kuantitatif yaitu suatu rumusan masalah yang berkenaan dengan pertanyaan terhadap keberadaan variabel mandiri, baik hanya pada satu variabel atau lebih (variabel mandiri adalah variabel yang berdiri sendiri, bukan variabel independen, karena kalau variabel independen selalu dipasangkan dengan variabel dependen).

Penelitian ini menggunakan teknik sampling purposive.Menurut Sugiyono 
(2012:122), sampling purposive adalah teknik penentuan sampel dengan pertimbangan tertentu.

Beberapa kriteria penentuan sampel perusahaan dalam penelitian ini adalah :

1. Perusahaan consumer goods yang terdaftar di BEI untuk periode 2013 2017.
2. Perusahaan consumer goods yang tidak menghasilkan laba positif periode 2013 2017.

3. Perusahaan consumer goods yang relisting di BEI selama periode 2013 2017.

4. Perusahaan consumer goods yang delisting di BEI selama periode 2013-2017.

Tabel II.1

Kriteria Sampel Penelitian

\begin{tabular}{|c|l|c|}
\hline No. & \multicolumn{1}{|c|}{ Keterangan } & Jumlah \\
\hline 1. & Perusahaan consumer goods yang terdaftar di BEI untuk periode 2013-2017. & 42 \\
\hline 2. & $\begin{array}{l}\text { Perusahaan consumer goods yang tidak menghasilkan laba positif selama } \\
\text { periode 2013 - 2017. }\end{array}$ & $(7)$ \\
\hline 3. & Perusahaan consumer goods yang re-listing di BEIselama periode 2013-2017. & $(1)$ \\
\hline 4. & Perusahaan consumer goods yang de-listing di BEI selama periode 2013-2017. & $(10)$ \\
\hline & Jumlah perusahaan yang terpilih menjadi sampel penelitian & 24 \\
\hline & Jumlah sampel selama pengamatan (5 tahun x 24 sampel) & 120 \\
\hline
\end{tabular}

Sumber : www.idx.co.id (data diolah)

\section{Hasil Penelitian dan Pembahasan}

IV.1 Hasil Uji Asumsi Klasik

\section{Uji Normalitas}

Uji normalitas digunakan untuk menguji apakah data berdistribusi dengan normal atau tidak yaitu melalui analisis grafik dan analisis statistik

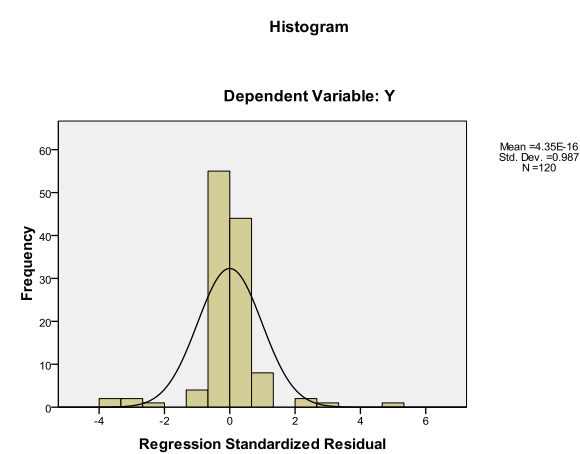

Gambar IV.1

Hasil Uji Asumsi Klasik Normalitas Histogram

(Sebelum Transformasi Data)

Sumber : Hasil Olahan Data SPSS Versi

\section{7, 2019}

Hasil grafik histogram menunjukkan adanya gambaran pola data yang kurang baik yang dapat dilihat dengan tampilan pola data pada gambar IV.1 menunjukkan tidak mengikuti garis ketentuan kurva berbentuk lonceng. Dengan demikian maka hasil ini juga tidak memenuhi syarat karena data tidak berdistribusi secara normal.

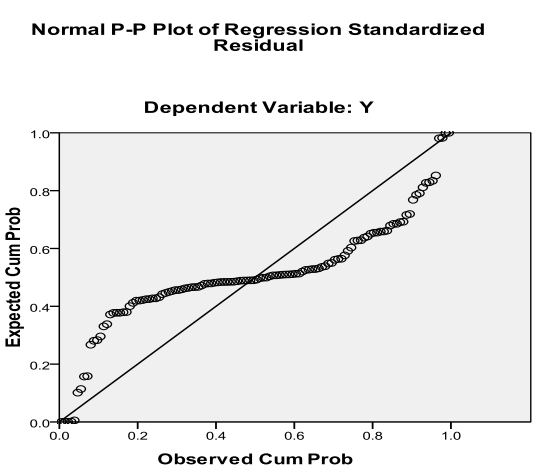

Gambar IV.2

Hasil Uji Asumsi Klasik Normalitas Probability Plot

(Sebelum Transformasi Data)

Sumber : Hasil Olahan Data SPSS Versi 17, 2019

Berdasarkan hasil uji normality probability plotpada gambar IV.2 menunjukkan adanya pola data yang melenceng dari ketentuan yaitu pola data / titik-titik tidak menyebar disekitar garis diagonal melainkan titik-titik saling berhimpit disekitar garis digonal. Dengan demikian maka hasil ini tidak memenuhi syarat karena data tidak berdistribusi secara normal. Untuk mengatasi agar kedua hasil uji 
normalitas dapat berdistribusi dengan normal maka dilakukan transformasi data dengan menggunakan Ln.

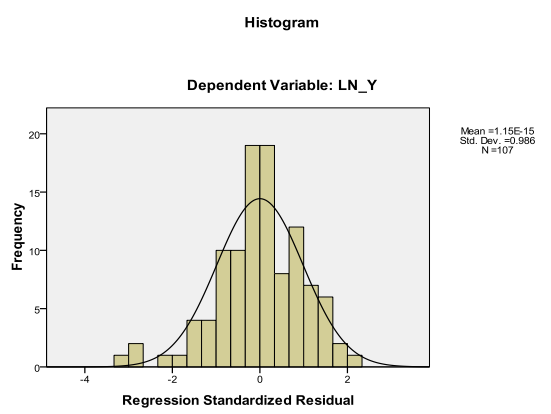

Gambar IV.3

Hasil Uji Asumsi Klasik Normalitas Histogram

(Setelah Transformasi Data)

Sumber : Hasil Olahan Data SPSS Versi

\section{7, 2019}

Berdasarkan hasil grafik histogram pada gambar IV.3 dapat menunjukkan bahwa kurva dependent dan regression standarized residual membentuk gambar seperti lonceng sehingga terlihat bahwa residual dihasilkan berdistribusi secara normal dan memenuhi asumsi normalitas dari data yang telah ditransformasi layak diterima.
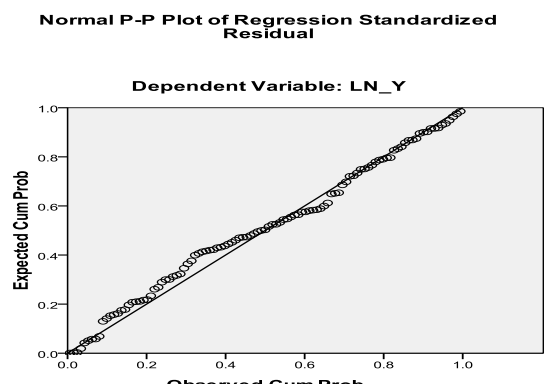

Gambar IV.4

Hasil Uji Asumsi Klasik Normalitas Probability Plot

(Setelah Transformasi Data)

Sumber : Hasil Olahan Data SPSS Versi 17, 2019

Berdasarkan hasil grafik normalityprobability plotpada gambar IV.4 menunjukkan bahwa titik-titik menyebar di sekitar garis diagonal sehingga memenuhi asumsi normalitas dari data yang telah ditransformasi layak diterima.

Tabel IV.1

One-Sample Kolmogorov-Smirnov Test

\begin{tabular}{|ll|r|}
\hline & & Unstandardized Residual \\
\hline N & & 120 \\
Normal Parameters ${ }^{\mathrm{a}, \mathrm{b}}$ & Mean & .0003088 \\
& Std. Deviation & 683969718788.39590000 \\
Most Extreme Differences & Absolute & .245 \\
& Positive & .189 \\
& Negative & -.245 \\
Kolmogorov-Smirnov Z & & 2.685 \\
Asymp. Sig. (2-tailed) & .000 \\
\hline a. Test distribution is Normal. \\
b. Calculated from data.
\end{tabular}

Sumber : Hasil Olahan Data SPSS Versi 17, 2019

Berdasarkan hasil uji Kolmogorov-Smirnov

$\mathrm{Z}$ dan Asymp. Sig. (2-tailed) pada tabel IV.1 sebelum data ditransformasi (Ln) yaitu sebesar 2,685 dan 0,000. Data One Sample Kolmogorov-Smirnov menunjukkan nilai
Kolmogorov-Smirnov Z dan Asymp. Sig. (2tailed $)>$ nilai probabilitas $(0,05)$ yaitu $0,000<$ 0,05 maka data tidak berdistribusi secara normal. 
Tabel IV.2

One-Sample Kolmogorov-Smirnov Test

\begin{tabular}{|ll|r|}
\hline & & Unstandardized Residual \\
\hline Normal Parameters ${ }^{\mathrm{a}, \mathrm{b}}$ & & \\
& Mean & .0000000 \\
& Std. Deviation & .47800650 \\
Most Extreme Differences & Absolute & .080 \\
& Positive & .055 \\
& Negative & -.080 \\
Kolmogorov-Smirnov Z & & .829 \\
Asymp. Sig. (2-tailed) & & .498 \\
\hline
\end{tabular}

a. Test distribution is Normal.

b. Calculated from data.

Sumber : Hasil Olahan Data SPSS Versi 17, 2019

Berdasarkan hasil uji Kolmogorov-Smirnov

$\mathrm{Z}$ dan Asymp. Sig. (2-tailed) pada tabel IV.2 setelah data dilakukan transformasi (Ln) yaitu sebesar 0,829 dan 0,498. Data One Sample Kolmogorov-Smirnov menunjukkan nilai Kolmogorov-Smirnov Z dan Asymp. Sig. (2tailed) > nilai probabilitas $(0,05)$ yaitu $0,498>$ 0,05 maka data telah berdistribusi bersifat normal. Dengan demikian, data dalam penelitian ini berdistribusi normal.

\section{Uji Multikolinieritas}

Uji yang digunakan untuk menguji apakah model regresi ditemukan adanya korelasi antar variabel bebas (independen) merupakan uji multikolinieritas.

Tabel IV.3

Coefficients $^{\mathrm{a}}$

\begin{tabular}{|c|c|c|c|c|c|c|c|}
\hline \multirow[b]{2}{*}{ Model } & \multicolumn{2}{|c|}{ Unstandardized Coefficients } & \multirow{2}{*}{$\begin{array}{c}\begin{array}{c}\text { Standardized } \\
\text { Coefficients }\end{array} \\
\text { Beta } \\
\end{array}$} & \multirow[b]{2}{*}{$t$} & \multirow[b]{2}{*}{ Sig. } & \multicolumn{2}{|c|}{ Collinearity Statistics } \\
\hline & B & Std. Error & & & & Tolerance & VIF \\
\hline 1 (Constant) & -31615756787.854 & 74468903112.315 & & -.425 & .672 & & \\
\hline $\mathrm{X} 1$ & .100 & .009 & .886 & 11.386 & .000 & .086 & 11.580 \\
\hline $\mathrm{X} 2$ & -.091 & .023 & -.201 & -3.987 & .000 & .206 & 4.862 \\
\hline $\mathrm{X} 3$ & .253 & .048 & .272 & 5.299 & .000 & .199 & 5.037 \\
\hline
\end{tabular}

a. Dependent Variable: Y

\section{Sumber : Hasil Olahan Data SPSS Versi 17, 2019}

Berdasarkan hasil uji multikolinieritas sebelum data dilakukan transformasi pada tabel IV.3 di atas menunjukkan bahwa hasil nilai tolerance variabel independen yaitu sales memiliki nilai tolerance $\leq 0,10$ dan nilai VIF $\geq$ 10 maka model penelitian ini terjadi multikolinieritas. Sedangkan working capital dan operating cash flowmemiliki nilai tolerance lebih $\geq 0,10$ dan nilai VIF $\leq 10$ maka model penelitian ini tidakterjadi multikolinieritas.

Tabel IV.4

Coefficients $^{\mathrm{a}}$

\begin{tabular}{|c|c|c|c|c|c|c|c|}
\hline \multirow[b]{2}{*}{ Model } & \multicolumn{2}{|c|}{ Unstandardized Coefficients } & \multirow{2}{*}{$\begin{array}{c}\begin{array}{c}\text { Standardized } \\
\text { Coefficients }\end{array} \\
\text { Beta }\end{array}$} & \multirow[b]{2}{*}{$\mathrm{t}$} & \multirow[b]{2}{*}{ Sig. } & \multicolumn{2}{|c|}{ Collinearity Statistics } \\
\hline & B & Std. Error & & & & Tolerance & VIF \\
\hline 1 (Constant) & -3.245 & .849 & & -3.821 & .000 & & \\
\hline LN_X1 & .420 & .072 & .360 & 5.843 & .000 & .158 & 6.343 \\
\hline LN_X2 & .396 & .065 & .389 & 6.122 & .000 & .148 & 6.741 \\
\hline LN_X3 & .250 & .049 & .261 & 5.157 & .000 & .235 & 4.257 \\
\hline
\end{tabular}

a. Dependent Variable: LN_Y 


\section{Sumber : Hasil Olahan Data SPSS Versi 17, 2019}

Berdasarkan hasil uji multikolinieritas setelah data dilakukan transformasi pada tabel IV.4 di atas menunjukkan bahwa hasil nilai tolerance ketiga variabel independen yaitu sales,working capital dan operating cash flowmemiliki nilai tolerance lebih $\geq 0,10$ dan nilai $\mathrm{VIF} \leq 10$ maka model penelitian ini tidakterjadi multikolinieritas.

\section{Uji Autokolerasi}

Uji yang digunakan untuk menguji apakah dalam model regresi linear ada korelasi antara kesalahan pengganggu pada periode $t$ dengan kesalahan pengganggu pada periode t-1 (sebelumnya). Salah satu ukuran dalam menentukan ada tidaknya masalah autokorelasi dengan uji Run Test.

\section{Tabel IV.5}

Runs Test

\begin{tabular}{|c|c|}
\hline & Unstandardized Residual \\
\hline Test Value $^{\mathrm{a}}$ & -15358504843.98473 \\
Cases < Test Value & 60 \\
Cases >= Test Value & 60 \\
Total Cases & 120 \\
Number of Runs & 60 \\
Z & -.183 \\
Asymp. Sig. (2-tailed) & .855 \\
\hline
\end{tabular}

\section{Sumber : Hasil Olahan Data SPSS Versi 17, 2019}

Berdasarkan hasil uji run test sebelum dilakukan transformasi padatabel IV.5 di atas menunjukkan hasil pengolahan data diperoleh nilai statistik nilai Test Value adalah - 15358504843,98473dengan probabilitas sebesar $0,885>0,05$ yang berarti bahwa tidak terdapat masalah autokorelasi dalam penelitian ini.

\section{Tabel IV.6}

Runs Test

\begin{tabular}{|l|r|}
\hline & \multicolumn{2}{|c|}{ Unstandardized Residual } \\
\hline Test Value $^{\mathrm{a}}$ & .00312 \\
Cases < Test Value & 53 \\
Cases > = Test Value & 54 \\
Total Cases & 107 \\
Number of Runs & 58 \\
$Z$ & .681 \\
Asymp. Sig. (2-tailed) & .496 \\
\hline a. Median
\end{tabular}

\section{Sumber : Hasil Olahan Data SPSS Versi 17, 2019}

Berdasarkan hasil uji run test setelah dilakukan transformasi pada tabel IV.6 di atas menunjukkan hasil pengolahan data diperoleh nilai statistik nilai Test Value adalah 0,00312dengan probabilitas sebesar 0,496 $>0,05$ yang berarti bahwa tidak terdapat masalah autokorelasi dalam penelitian ini.

\section{Uji Heteroskedastisitas}

Uji yang digunakan untuk menguji apakah dalam model regresi terjadi ketidaksamaan variance dari residual satu pengamatan ke pengamatan yang lain adalah uji
heterokedastisitas.Berikut adalah hasil uji heteroskedastisitas variabel yang digunakan dalam penelitian yaitu uji grafik dan uji statistik. 


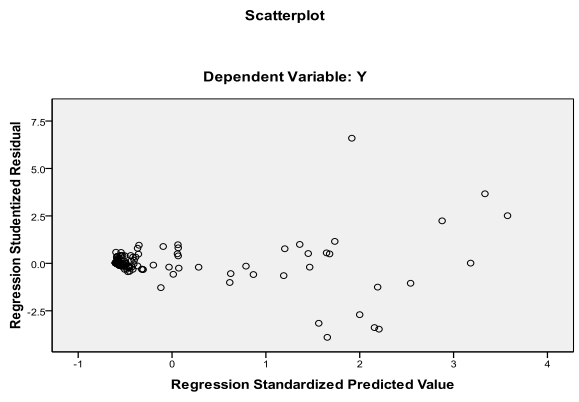

Gambar IV.5

Hasil Uji Heteroskedastisitas-Scatterplot (Sebelum Transformasi Data)

Sumber : Hasil Olahan Data SPSS Versi 17, 2019

Berdasarkan hasil uji heteroskedastisitas pada gambar IV.5 di atas sebelum dilakukan transformasi pada grafik scatterplot di atas dinyatakan telah terjadi heteroskedastisitas.

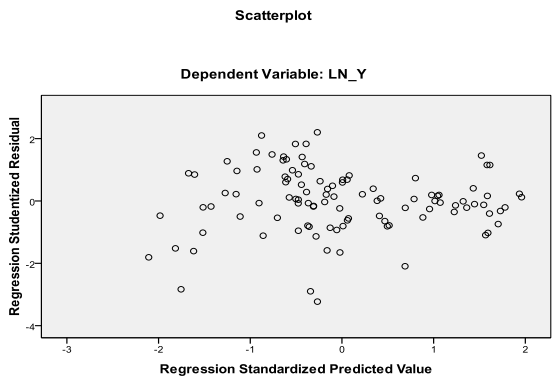

Gambar IV.6

Hasil Uji Heteroskedastisitas -Scatterplot (Setelah Transformasi Data)

\section{Sumber : Hasil Olahan Data SPSS Versi} 17, 2019

Berdasarkan hasil uji heteroskedastisitas pada gambarIV.6 di atas, hasil setelah ditransformasi menunjukkan bahwa tidak terjadi heteroskedastisitas pada model sehingga model penelitian ini layak dipakai.

Tabel IV.7

Coefficients $^{\mathrm{a}}$

\begin{tabular}{|c|c|c|c|c|c|c|c|}
\hline \multirow[b]{2}{*}{ Model } & \multicolumn{2}{|c|}{ Unstandardized Coefficients } & \multirow{2}{*}{$\begin{array}{c}\text { Standardized } \\
\text { Coefficients } \\
\text { Beta }\end{array}$} & \multirow[b]{2}{*}{$\mathrm{t}$} & \multirow[b]{2}{*}{ Sig. } & \multicolumn{2}{|c|}{$\begin{array}{l}\text { Collinearity } \\
\text { Statistics }\end{array}$} \\
\hline & B & Std. Error & & & & Tolerance & VIF \\
\hline 1 (Constant) & 70548967946.800 & 42121504744.105 & & 1.675 & .097 & & \\
\hline $\mathrm{X} 1$ & .015 & .005 & .617 & 2.987 & .003 & .086 & 11.580 \\
\hline $\mathrm{X} 2$ & .022 & .013 & .231 & 1.730 & .086 & .206 & 4.862 \\
\hline $\mathrm{X} 3$ & -.017 & .027 & -.084 & -.619 & .537 & .199 & 5.037 \\
\hline
\end{tabular}

a. Dependent Variable: ABS_RES1

Sumber : Hasil Olahan Data SPSS Versi17, 2019

Berdasarkan tabelIV.7 di atas terlihat bahwa nilai signifikan working capital dan operating cash flowpada uji glejtser $\geq 0,05$ yang berarti

tidak terjadi heteroskedastisitas akan tetapi sales pada uji glejtser $\leq 0,05$ dapat disimpulkanterjadi heteroskedastisitas.

Tabel IV.8

Coefficients $^{a}$

\begin{tabular}{|c|c|c|c|c|c|c|c|c|}
\hline & \multirow[b]{2}{*}{ Model } & \multicolumn{2}{|c|}{ Unstandardized Coefficients } & \multirow{2}{*}{$\begin{array}{c}\begin{array}{c}\text { Standardized } \\
\text { Coefficients }\end{array} \\
\text { Beta }\end{array}$} & \multirow[b]{2}{*}{$\mathrm{t}$} & \multirow[b]{2}{*}{ Sig. } & \multicolumn{2}{|c|}{ Collinearity Statistics } \\
\hline & & B & Std. Error & & & & Tolerance & VIF \\
\hline \multirow[t]{4}{*}{1} & (Constant) & 2.106 & .530 & & 3.974 & .000 & & \\
\hline & LN_X1 & -.041 & .045 & -.216 & -.923 & .358 & .158 & 6.343 \\
\hline & LN_X2 & -.007 & .040 & -.041 & -.168 & .867 & .148 & 6.741 \\
\hline & LN_X3 & -.014 & .030 & -.087 & -.452 & .652 & .235 & 4.257 \\
\hline
\end{tabular}

a. Dependent Variable: ABS_RES3

Sumber : Hasil Olahan Data SPSS Versi 17, 2019

Berdasarkanhasil uji glejtser pada tabel IV.8 di atas terlihat bahwa seluruh variabel independen yaitu sales dengan nilai signifikan 0,358 , working capital dengan nilai signifikan
0,867 dan operating cash flow dengan nilai signifikan $0,652 \geq$ nilai signifikan 0,05 . Hal ini menunjukkan bahwa model regresi tidak terjadi heteroskedastisitas. 


\section{IV.2 Hasil Analisis Data Penelitian}

Analisis Regresi Linear Berganda

Analisis regresi linear berganda digunakan untuk mencari hubungan atau pengaruh antar variabel independen (sales, working capital dan operating cash flow) terhadap variabel dependen (net profit).

Tabel IV.9

\begin{tabular}{|c|c|c|c|c|c|}
\hline \multirow[b]{2}{*}{ Model } & \multicolumn{2}{|c|}{$\begin{array}{l}\text { Unstandardized } \\
\text { Coefficients }\end{array}$} & \multirow{2}{*}{$\begin{array}{c}\begin{array}{c}\text { Standardized } \\
\text { Coefficients }\end{array} \\
\text { Beta }\end{array}$} & \multirow[b]{2}{*}{$\mathrm{t}$} & \multirow[b]{2}{*}{ Sig. } \\
\hline & B & Std. Error & & & \\
\hline 1 (Constant) & -3.245 & .849 & & -3.821 & .000 \\
\hline LN_X1 & .420 & .072 & .360 & 5.843 & .000 \\
\hline LN_X2 & .396 & .065 & .389 & 6.122 & .000 \\
\hline LN_X3 & .250 & .049 & .261 & 5.157 & .000 \\
\hline
\end{tabular}

\section{Sumber : Hasil Pengolahan Data SPSS Versi 17, 2019}

Persamaan regresi linear berganda dalam penelitian ini berdasarkan tabel IV.9 tersebut adalah sebagai berikut :

Net Profit $=-3,245+0,420$ Sales $+0,396$ Working Capital+0,250Operating Cash Flow Keterangan :

$$
\begin{array}{ll}
\mathrm{Y} & =\text { Net Profit } \\
\mathrm{X}_{1} & =\text { Sales } \\
\mathrm{X}_{2} & =\text { Working Capital } \\
\mathrm{X}_{3} & =\text { Operating Cash Flow }
\end{array}
$$

Persamaan regresi tersebut dapat diuraikan sebagai berikut :

1. Nilai Constant (a) $=-3,245$

Nilai konstanta ini menunjukkan bahwa apabila nilai variabel bebas yaitu sales, working capital dan operating cash flow bernilai konstan, maka nilai net profit sebesar $-3,245$.

2. Nilai $b_{1}=0,420$ pada variabel Sales

Koefisien regresi ini menunjukkan bahwa setiap kenaikan sales sebesar 1 satuan, maka net profit mengalami kenaikan sebesar 0,420 dengan asumsi variabel lain dianggap konstan. 3. Nilai $\mathrm{b}_{2}=0,396$ pada variabel Working Capital

Koefisien regresi ini menunjukkan bahwa setiap kenaikan working capital sebesar 1 satuan, maka net profit mengalami kenaikan sebesar 0,396 dengan asumsi variabel lain dianggap konstan.

4. Nilai $\mathrm{b}_{3}=0,250$ pada variabel Operating Cash Flow

Koefisien regresi ini menunjukkan bahwa setiap kenaikan operating cash flowsebesar 1 satuan, maka net profit mengalami penurunan sebesar 0,250 dengan asumsi variabel lain dianggap konstan.

\section{Koefisien Determinasi $\left(\mathbf{R}^{\mathbf{2}}\right)$}

Nilai koefisien determinasi digunakan untuk mengukur seberapa besar pengaruh sales, working capital dan operating cash flowterhadap net profit pada perusahaanconsumer goods di BEI.

Tabel IV.10

Model Summary ${ }^{b}$

\begin{tabular}{|l|r|r|r|r|}
\hline Model & \multicolumn{1}{|c|}{ R } & R Square & Adjusted R Square & $\begin{array}{c}\text { Std. Error of the } \\
\text { Estimate }\end{array}$ \\
\hline 1 & $.969^{\mathrm{a}}$ & .938 & .936 & .48492 \\
\hline
\end{tabular}

a. Predictors: (Constant), LN_X3, LN_X1, LN_X2

b. Dependent Variable: LN_Y

Sumber : Hasil Olahan Data SPSS Versi 17, 2019

Berdasarkan tabel IV.10 menunjukkan bahwa hubungan yang terjadi antara sales, working capital dan operating cash flowsebagai variabel independen dan net profit sebagai variabel dependen menunjukkan hubungan yang sangat tinggi.
Hal ini terlihat dari nilai $R$ Square menunjukkan sebesar 0,938 atau sekitar 93,8\% yang berarti variabelindependen dapat menjelaskan $93,8 \%$ variabel net profit sedangkan sisanya sebesar $6,2 \%$ merupakan 
pengaruh dari variabel bebas lain yang tidak diteliti dalam penelitian ini.

Pengujian Hipotesis Secara Simultan
Uji ini bertujuan untuk menunjukkan bagaimana pengaruh variabel independen terhadap variabel dependen secara bersamasama.

Tabel IV.11

ANOVA $^{b}$

\begin{tabular}{|cl|c|c|c|c|c|}
\hline & Model & Sum of Squares & Df & Mean Square & F & Sig. \\
\hline 1 & Regression & 367.610 & 3 & 122.537 & 521.111 & $.000^{\mathrm{a}}$ \\
& Residual & 24.220 & 103 & .235 & & \\
& Total & 391.830 & 106 & & & \\
\end{tabular}

a. Predictors: (Constant), LN_X3, LN_X1, LN_X2

b. Dependent Variable: LN_Y

Sumber : Hasil Olahan Data SPSS Versi 17, 2019

Berdasarkan hasil uji $\mathrm{F}$ pada tabel IV.11 diperoleh nilaiF ${ }_{\text {hitungsebesar }}$ 521,111. Pada derajat bebas $1\left(\mathrm{df}_{1}\right)=\mathrm{k}-1=4-1=3$, dan derajat bebas $2\left(\mathrm{df}_{2}\right)=\mathrm{n}-\mathrm{k}=120-4=116$, dimana $\mathrm{n}=$ jumlah sampel, $\mathrm{k}=$ jumlah variable, nilai $F_{\text {tabel }}$ pada taraf kepercayaan signifikan 0,05 adalah 2,68. Dengan demikian nilai $\mathrm{F}_{\text {hitung }}=521,111>\mathrm{F}_{\text {tabel }}=2,68$ dengan tingkat signifikan 0,000. Maka Ha diterima artinya sales, working capital dan operating cash flow secara simultan berpengaruh dan signifikan terhadap net profitpada perusahaan consumer goods yang terdaftar di Bursa Efek Indonesia periode 2013-2017.

\section{Pengujian Hipotesis Secara Parsial}

Tujuan dilakukannya uji t (parsial) ini yaitu untuk melihat seberapa jauh pengaruh satu variabel independen terhadap variabel dependen secara individual.

Tabel IV.12

Coefficients $^{a}$

\begin{tabular}{|c|c|c|c|c|c|}
\hline \multirow[b]{2}{*}{ Model } & \multicolumn{2}{|c|}{$\begin{array}{c}\text { Unstandardized } \\
\text { Coefficients }\end{array}$} & \multirow{2}{*}{$\begin{array}{c}\begin{array}{c}\text { Standardized } \\
\text { Coefficients }\end{array} \\
\text { Beta } \\
\end{array}$} & \multirow[b]{2}{*}{$\mathrm{t}$} & \multirow[b]{2}{*}{ Sig. } \\
\hline & B & Std. Error & & & \\
\hline 1 (Constant) & -3.245 & .849 & & -3.821 & .000 \\
\hline LN_X1 & .420 & .072 & .360 & 5.843 & .000 \\
\hline LN_X2 & .396 & .065 & .389 & 6.122 & .000 \\
\hline LN_X3 & .250 & .049 & .261 & 5.157 & .000 \\
\hline
\end{tabular}

Sumber : Hasil Olahan Data SPSS Versi 17, 2019

Berdasarkan hasil uji $t$ pada tabel 14 diperoleh nilai t tabel untuk net profit pada derajat bebas $\mathrm{df}=\mathrm{n}-\mathrm{k}=120-4=116$ dengan nilai signifikansi 0,05 adalah sebesar 1,65810. Dengan demikian hasil dari uji $\mathrm{t}$ dapat dijelaskan sebagai berikut:

1. Pada variabel sales $t_{\text {hitung }}>t_{\text {tabel }}(5,843>$ $1,65810)$ dan nilai signifikan $(0,000<$ $0,05)$ maka $\mathrm{H}_{0}$ ditolak yaitu sales berpengaruh positif dan signifikan terhadap net profit pada perusahaan consumer goods yang terdaftar di Bursa Efek Indonesia periode 2013-2017.

2. Pada variabel working capital $t_{\text {hitung }}>t_{\text {tabel }}$ $(6,122>1,65810)$ dan nilai signifikan $(0,000<0,05)$ maka $\mathrm{H}_{0}$ ditolak yaitu working capital berpengaruh positif dan signifikan terhadap net profit pada perusahaan consumer goods yang terdaftar di Bursa Efek Indonesia periode 2013-2017.

3. Pada variabel operating cash flow thitung $>$ $\mathrm{t}_{\text {tabel }}(5,157>1,65810)$ dan nilai signifikan $(0,000<0,05)$ maka $\mathrm{H}_{0}$ ditolak yaitu operating cash flow berpengaruh positif dan signifikan terhadap net profit pada perusahaan consumer goods yang terdaftar di Bursa Efek Indonesia periode 2013-2017.

\section{IV.4 Pembahasan Hasil Penelitian Pengaruh Sales Terhadap Net Profit}

Berdasarkan hasil pengujian secara parsial (Uji t) diperoleh $t_{\text {hitung }}>t_{\text {tabel }}(5,843>1,65810)$ maka $\mathrm{H}_{0}$ ditolak dan $\mathrm{H}_{1}$ diterima pada $\alpha=5 \%$ dengan nilai signifikan $0,000<0,05$. Dengan 
demikian sales berpengaruh positif dan signifikan terhadap net profit pada perusahaan consumer goods yang terdaftar di Bursa Efek Indonesia periode 2013-2017.Hasil ini sejalan dengan penelitian sebelumnya yang dilakukan Teratai (2017) yang menyatakan bahwa sales berpengaruh signifikan terhadap net profit.Berdasarkan hasil penelitian di atas maka dapat disimpulkan bahwa pada perusahaan consumer goods di Bursa Efek Indonesia menunjukkan bahwa ada hubungan antara sales dengan net profit perusahaan karena dalam hal ini laba akan timbul jika penjualan produk lebih besar dibandingkan dengan biaya-biaya yang dikeluarkan. Laba bersih diharapkan akan meningkat selama penjualan tersebut lebih besar daripada biaya yang dikeluarkan.

\section{Pengaruh Working Capital Terhadap Net Profit}

Berdasarkan hasil pengujian secara parsial (Uji t) diperoleh maka $t_{\text {hitung }}>t_{\text {tabel }}(6,122>$ 1,65810)maka $\mathrm{H}_{0}$ ditolak dan $\mathrm{H}_{1}$ diterima pada $\alpha=5 \%$ dengan nilai signifikan $0,000<$ 0,05 . Dengan demikian net profitberpengaruh positif dan signifikan terhadap net profitpada perusahaan consumer goods yang terdaftar di Bursa Efek Indonesia periode 20132017.Hasil ini sejalan dengan penelitian sebelumnya yang dilakukan Teratai (2017) dan Zaenal Abidin dan Dewi Ariani (2014) yang menyatakan bahwa working capital berpengaruh signifikan terhadap net profit.Berdasarkan hasil penelitian di atas maka dapat disimpulkan bahwa pada perusahaan consumer goods di Bursa Efek Indonesia menunjukkan bahwa modal kerja yang diproduktif digunakan untuk kegiatan operasi mampu meningkatkan laba bersih.

\section{PengaruhOperating Cash Flow Terhadap Net Profit}

Berdasarkan hasil pengujian secara parsial (Uji t ) diperoleh $t_{\text {hitung }}>t_{\text {tabel }}(5,157>1,65810)$ maka $\mathrm{H}_{0}$ ditolak dan $\mathrm{H}_{1}$ diterima pada $\alpha=5 \%$ dengan nilai signifikan $0,000<0,05$. Dengan demikian operating cash flow berpengaruh positif dan signifikan terhadap net profit pada perusahaan consumer goods yang terdaftar di Bursa Efek Indonesia periode 20132017.Hasil ini sejalan dengan penelitian sebelumnya yang dilakukan Sutardi dan Adi Sulaeman (2011) yang menyatakan bahwa berpengaruh signifikan terhadap net profit. Berdasarkan hasil penelitian di atas maka dapat disimpulkan bahwa pada perusahaan consumer goods di Bursa Efek Indonesia menunjukkan bahwa kas yang dikeluarkan relatif kecil maka perusahaan akan memperoleh keuntungan.

\section{Pengaruh Sales, Working Capital dan Operating Cash Flow Terhadap Net Profit}

Berdasarkan hasil pengujian secara simultan (uji F) diperoleh nilaiF $F_{\text {hitung }}>F_{\text {tabel }}$ $(521,111>2,68)$ maka $\mathrm{H}_{0}$ ditolak dan $\mathrm{Ha}$ diterima pada $\alpha=5 \%$ dengan nilai $0,000<$ 0,05 . Dengan demikian sales, working capital dan operating cash flow secara simultan berpengaruh positif dan signifikan terhadap net profit pada perusahaan consumer goodsyang terdaftar di Bursa Efek Indonesia periode 2013-2017.

Sales, working capital dan operating cash flow secara bersama-sama memberi pengaruh yang kuat dalam meningkatkan net profit.

\section{KESIMPULAN}

Berdasarkan hasil pengujian, penelitian dan pembahasan yang telah dilakukan pada penelitian, maka peneliti akan menyimpulkan beberapa kesimpulan yaitu sebagai berikut :

1. Sales, working capital dan Operating cash flow berpengaruh signifikan secara parsial terhadap net profit perusahaan consumer goods yang terdaftar di Bursa Efek Indonesia periode 2013-2017.

2. Sales, working capital dan operating cash flow berpengaruh positif dan signifikan secara simultan terhadap net profit perusahaan consumer goods yang terdaftar di Bursa Efek Indonesia periode 2013-2017, dengan nilai R Square menjelaskan pengaruh variabel independen terhadap variabel dependen sebesar $93,8 \%$ dan sisanya sebesar $6,2 \%$ dipengaruhi oleh faktor-faktor lain diluar variabel diantaranya.

\section{DAFTAR PUSTAKA}


Jurnal Ilmiah Prodi Manajemen Universitas Pamulang Vol.2 No.1, Oktober. Hlm: 146-163

Brigham, Eugene F \& Joel F.Houston. 2012.

Dasar-Dasar Manajemen

Keuangan. Edisi 11. Jakarta: Salemba Empat

Fahmi, Irham. 2012. Pengantar Manajemen Keuangan Teori dan Soal Jawab. Bandung: Alfabeta

Hery. 2013. Teori Akuntansi Suatu Pengantar. Jakarta: Lembaga Penerbit Fakultas Ekonomi Universitas Indonesia

Hery. 2014. Analisis Kinerja Manajemen. Jakarta: PT.Grasindo

Kasmir. 2015. Analisis Laporan Keuangan. Edisi kedelapan. Jakarta: PT.RajaGrafindo Persada

Munawir. 2014. Analisa Laporan Keuangan. Edisi 4. Yogyakarta: Liberty

Soemarso. 2009. Akuntansi Suatu Pengantar. Edisi 5. Jakarta: Salemba Empat

Sudana, Made I. 2011. Manajemen Keuangan Perusahaan Teori dan Praktik. Jakarta: Erlangga

Sugiyono. 2012. Metode Penelitian Bisnis. Bandung: Alfabeta

Sunyoto, Danang. 2013. Analisis Laporan Keuangan untuk Bisnis (Teori dan Kasus). Edisi Pertama. Yogyakarta: CAPS

Sutarti \& Adi Sulaeman. 2011. Pengaruh Arus Kas Operasi Terhadap Pertumbuhan Laba Perusahaan Studi Kasus pada PT.Multi Manunggal. Jurnal Ilmiah
Ranggagading Vol.11 No.2, Oktober. Hlm: 117-125

Teratai, Bunga. 2017.Pengaruh Modal Kerja dan Penjualan Terhadap Laba Bersih Pada Perusahaan Sub Sektor Food and Beverage yang Terdaftar di Bursa Efek Indonesia Periode 20112015. eJournal Administrasi Bisnis Vol.5 No.2. Hlm: 297-308 